\title{
Comparison of Soil Bacterial Community Structure in Rice Paddy Fields under Different Management Practices using Terminal Restriction Fragment Length Polymorphism (T-RFLP)
}

\author{
Kim, Do Young ${ }^{1}$, Chang-Gi Kim¹, Sang Mok Sohn ${ }^{2}$ and Sangkyu Park ${ }^{3 *}$ \\ ${ }^{1}$ Bio-Evaluation Center, Korea Research Institute of Bioscience and Biotechnology, Chungcheongbuk-Do 363-883, Korea \\ ${ }^{2}$ Research Institute of Organic Agriculture, Dankook University, Cheonan 330-714, Korea \\ ${ }^{3}$ Department of Biological Science, Ajou University, Suwon 443-749, Korea
}

\begin{abstract}
To develop a monitoring method for soil microbial communities in rice paddy fields, we used terminal restriction fragment length polymorphism (T-RFLP) to compare soil bacterial community structure in rice paddy fields experiencing different management practices: organic practices, conventional practices without a winter barley rotation, and conventional practices with a winter barley rotation. Restriction fragment length profiles from soils farmed using organic practices showed very different patterns from those from conventional practices with and without barley rotation. In principal component analyses, restriction fragment profiles in organic practice samples were clearly separated from those in conventional practice samples, while principal component analysis did not show a clear separation for soils farmed using conventional practices with and without barley rotation. The cluster analysis showed that the bacterial species compositions of soils under organic practices were significantly different from those under conventional practices at the $95 \%$ level, but soils under conventional practice with and without barley rotation did not significantly differ. Although the loadings from principal component analyses and the Ribosomal DNA Project II databases suggested candidate species important for soils under organic farming practices, it was very difficult to get detailed bacterial species information from terminal restriction fragment length polymorphism. Rank-abundance diagrams and diversity indices showed that restriction fragment peaks under organic farming showed high Pielou's Evenness Index and the reciprocal of Simpson Index suggesting high bacterial diversity in organically farmed soils.
\end{abstract}

Key words: Diversity indices, Organic farming practice, Rice paddy fields, Soil bacterial community, Terminal restriction fragment length polymorphism (T-RFLP)

\section{INTRODUCTION}

In recent years, molecular techniques using the polymerase chain reaction (PCR) to amplify the 16S rRNA gene, such as the terminal restriction fragment length polymorphism (T-RFLP) technique, have become popular for determining whole soil microbial communities (Liu et al. 1997, Marsh 1999). T-RFLP has several advantages over similar PCR-based techniques for the 16S rRNA gene such as denaturing gradient gel electrophoresis (DGGE) or temperature gradient gel electrophoresis (TGGE): direct reference to sequence databases such as the Ribosomal DNA Project (RDP), greater resolution than DGGE or TGGE, and output as digital profiles that make comparisons among different soil communities easy (Marsh 1999). Our recent risk assessment for a transgenic watermelon (Park et al. 2006a, Park et al. 2006b, Park 2007) resulted in the development of a molecular approach to elucidate soil bacterial community structure using terminal restriction fragment length polymorphism (T-RFLP).

As global interest in organic farming as an alternative to conventional farming practices has increased, much research has focused on the impact of farming practices on soil fertility and biodiversity (Drinkwater et al 1995, Mäder et al. 2002, Van Diepeningen et al. 2006). Since the 1970s, organic farming practices have developed in South Korea to produce safer foods free from chemical fertilizers and pesticides (Chung 2003). Soil bacterial communities play a major role in energy flow and nutrient cycling in soil food webs (Neher 1999). Therefore, the diversity of soil bacterial communities must be determined to study the relationship between soil diversity and function (Nannipieri et al. 2003).

In this study, we compared soil bacterial communities under organic and conventional management practices using T-RFLP. Our purposes were to identify characteristic bacterial species for soils being farmed using organic and conventional practices by analyzing T-RF profiles through principal component analysis (PCA) and to

\footnotetext{
* Corresponding author; Phone: +82-31-219-2967, e-mail: daphnia@ajou.ac.kr
} 
describe the diversity of soil bacterial communities using T-RF as representatives of each bacterial genotype.

\section{METHODS}

\section{Site Description and Sample Collection}

We collected soil samples from rice paddy fields in Hodong-ri, Beolgyo-eup, Boseong-gun, and Jeollanam-Do, Korea in 2004. Samples were collected from depths of $0 \sim 10 \mathrm{~cm}$ and $0 \sim 30 \mathrm{~cm}$ from rice paddy fields under organic practices (O-10, O-30), conventional practices (C-10, C-30) and conventional practices with crop rotation (CB-10, CB-30). Crop rotation with winter barley had already been conducted for 3 years in the crop rotation field when this study began. Only compost had been applied as fertilizer and no pesticides had been applied for 10 years in the organic paddy field when this study began. The field had been certified as "organic" by the National Agricultural Products Quality Management Service (NAQS, government certification body) of the Ministry of Agriculture and Forestry, Korea since 2001.

\section{T-RFLP}

Total DNA was extracted from the soils for T-RFLP analyses using the FastDNA SPIN KIT For Soil (Qbiogene, USA). The concentration of DNA was estimated using an UV spectrometer (Bio Rad Smart Spec 3000). We amplified the 16S rRNA gene using PCR using the extracted DNA as templates with fluorescence-dyelabeled 8F-FAM (5'-AGAGTTTGATCCTGGCTCAG-3') and unlabeled 1492R (5'-TACGGTTACCTTGTTACGACTT-3') primers (Bioneer, Korea). The reactions were conducted using $50 \mu \mathrm{L}$ (final volume) mixtures containing 10× Taq buffer (Neutrotics, Korea), $1 \mu \mathrm{L}$ of each deoxyribonucleoside triphosphate (Promega, USA) at a concentration of 10 pmol and $2 \mathrm{U}$ of Taq DNA polymerase (Neurotics Inc., Korea). Conditions for PCR were as follows: an initial denaturation step of $94^{\circ} \mathrm{C}$ for $3 \mathrm{~min}, 25$ amplification cycles of denaturation $\left(45 \mathrm{~s}\right.$ at $\left.94^{\circ} \mathrm{C}\right)$; annealing $\left(45 \mathrm{~s}\right.$ at $\left.55^{\circ} \mathrm{C}\right)$; and elongation (2 min at $70^{\circ} \mathrm{C}$ ); and a final extension step of $7 \mathrm{~min}$ at $72^{\circ} \mathrm{C}$ (Ritchie et al. 2000). We combined products from six PCR runs (total volume: $300 \mu \mathrm{L}$ ), followed by a purification step using Qiaquick PCR Purification Kits (Qiagen, Germany). One microgram of purified PCR product was digested with the restriction endonucleases HaeIII (Promega, USA) and HhaI (Promega, USA) at $37^{\circ} \mathrm{C}$ for $2 \mathrm{~h}$. The reactions were conducted using $20 \mu \mathrm{L}$ (final volume) mixtures containing $2 \mu \mathrm{L}$ of $10 \times$ buffer, $2 \mu \mathrm{L}$ of $10 \times$ Acetylated Bovine Serum Albumin supplied by the manufacturer (Promega, USA), and $1 \mu \mathrm{L}$ of the restriction endonuclease (10 U). Digests $(1 \sim 2 \mu \mathrm{L})$ were mixed with $12 \mu \mathrm{L}$ of formamide and $0.5 \mu \mathrm{L}$ of size standard (GeneScan-1000 ROX, Applied Biosystems). The samples were denatured at $60^{\circ} \mathrm{C}$ for 20 min and then placed on ice. Lengths of the restricted fragments were determined using an automated ABI DNA sequencer (Model 3100, Applied Biosystems, USA) for $1 \mathrm{~h} 32 \mathrm{~min} 10 \mathrm{~s}$. The fluorescently labeled 5'-terminal restriction fragments (T-RFs) were detected and analyzed using GeneScan 3.7 software (Applied Biosystems, USA) with size markers ranged between 29 and 677 which covered most of the major T-RFs.

\section{Principal Component Analyses and Cluster Analysis}

T-RF peaks identified by GeneScan 3.7 software from individual T-RFLP profiles were compiled and aligned to produce large data matrices (6 observations $\times 89$ peak variables for the HaeIII dataset and 6 observations $\times 80$ peak variables for the HhaI dataset). Centered T-RFLP profile data were used in PCA without any further normalization. We assigned a value of 0 if there was no matching peak. We then applied PCA to the weighted covariance data matrices to reduce their dimensionality. All statistical analyses except for cluster analysis were performed with S-Plus 6 for Windows (Insightful Corp., USA). Cluster analysis was conducted on candidate bacterial species lists obtained from the TAP-TRFLP menu on the RDP (Ribosomal DNA Project) II site (http://rdp.cme.msu.edu) using BOOTCLUS program (McKenna 2003). We used the BrayCurtis Coefficient for the similarity index and UPGMA as the linkage method.

\section{Diversity Indices}

We used genotype richness $(S)$, the Shannon diversity index $\left(H^{\prime}\right)$, Pielou's evenness index $(E)$ and the reciprocal of Simson index $(1 / D)$ as indices of diversity. $S$ was defined as the number of unique T-RF peaks for each T-RFLP profile. The Shannon diversity index was calculated as follows:

$$
H^{\prime}=-\sum\left(p_{i}\right)\left(\ln p_{i}\right)
$$

where the summation is over all values of $p_{i}$, the relative abundance of the unique restriction fragment $i$. The abundance of a particular T-RF peak can be determined using the intensity of fluorescence in fluorescence units. Pielou's evenness index was calculated as follows:

$$
E=H^{\prime} /(\ln [S])
$$

The reciprocal of Simpson index $(1 / D)$ was calculated as follows:

$$
1 / D=1 /\left(\sum p_{i}^{2}\right)
$$

Diversity indices were compared among bacterial communities using the Tukey multiple comparison test. 


\section{RESULTS}

\section{Restriction Fragment Length Profiles of Soils Under Different} Farming Practices

T-RF profiles from soils of paddy rice fields under conventional farming practices with and without barley rotation and under organic farming appeared to be different for both restriction enzymes (Fig. 1 and Fig. 2). In particular, the T-RF profiles from soils farmed using organic practices showed very different patterns from those farmed using conventional practices with and without barley rotation. Restriction fragment profiles produced using the HhaI enzyme showed very different patterns from profiles produced using the HaeIII enzyme. T-RF peaks in the HhaI dataset were closely aggregated relative to the T-RF peak patterns in the HaeIII dataset.

\section{Comparison of Bacterial Communities Using T-RFLP Profile Data}

We conducted PCA to summarize the T-RF profile data and to identify the most important T-RF peaks (Fig. 3). For the HaeIII enzyme dataset, PCA explained $83 \%$ of the total variation with the
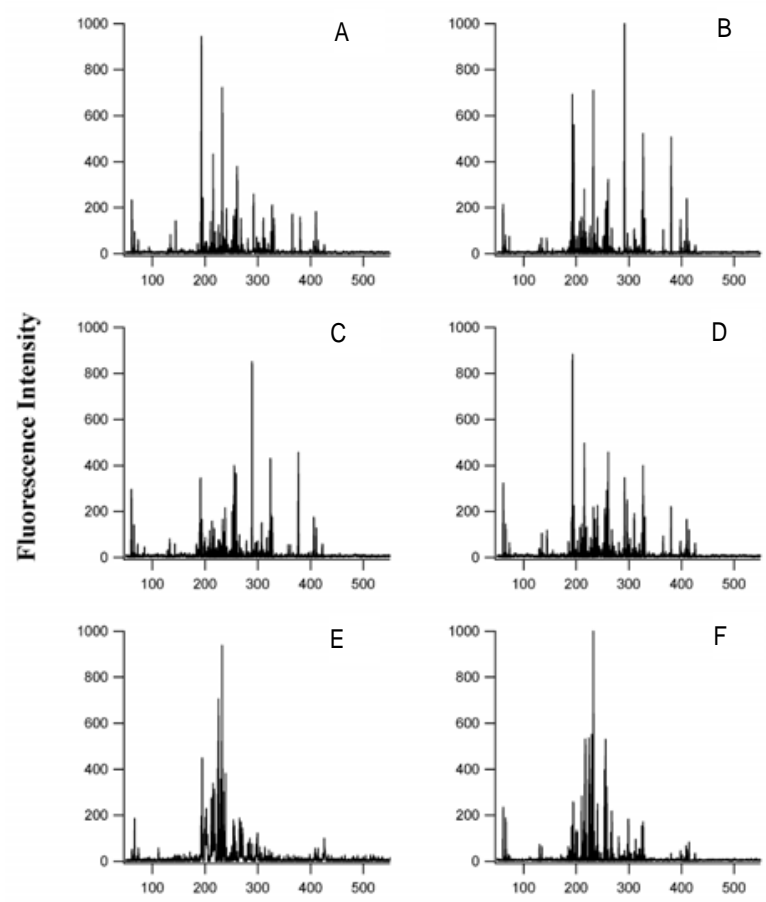

Fragment Length (bp)

Fig. 1. HaeIII restriction enzyme T-RFLP profiles of soils from rice fields under conventional farming (A and B), conventional farming with barley rotation (C and $\mathrm{D})$, and organic farming ( $\mathrm{E}$ and F). A: C-10 sample, B: C-30 sample, C: CB-10 sample, D: CB-30 sample, E: O-10 sample, F: O-30 sample. first and the second principal components. Restriction fragment profiles in organic-practice samples were clearly separated from those in conventional-practice samples along the first principal component, which explained $70.3 \%$ of the total variation. For the HhaI enzyme dataset, PCA explained $89.6 \%$ of the total variation with the first and the second principal components. Restriction fragment profiles in the organic-practice samples were clearly separated from those in conventional-practice samples along the second principal component, which explained $21.7 \%$ of the total variation. In both datasets, PCA scores of conventional-practice samples with and without barley rotation were not clearly separated.

Based on predicted lengths of T-RF peaks for HaeIII and HhaI enzymes from the RDP II database (http://rdp8.cme.msu.edu/html), we identified a total of 129 bacterial strain candidates including 52 genera and 87 species for the studied soils (data are not shown). We included species candidates only if the predicted lengths of T-RF peaks were found in the T-RF profiles for both HaeIII and HhaI. We performed a cluster analysis on a species presence/absence matrix for 6 soil samples. The cluster analysis showed that the bacterial species compositions of soils under organic practices
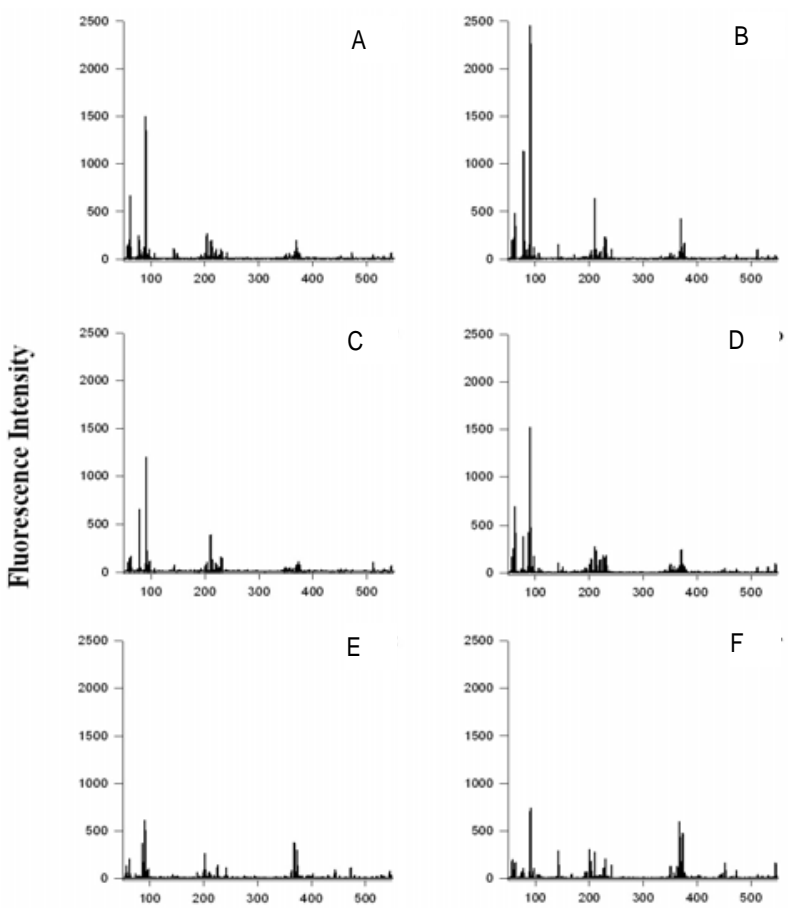

Fragment Length (bp)

Fig. 2. HhaI restriction enzyme T-RFLP profiles of soils from rice fields under conventional farming (A and B), conventional farming with barley rotation (C and $D)$, and organic farming (E and F). A: C-10 sample, B: C-30 sample, C: CB-10 sample, D: CB-30 sample, E: O-10 sample, F: O-30 sample. 

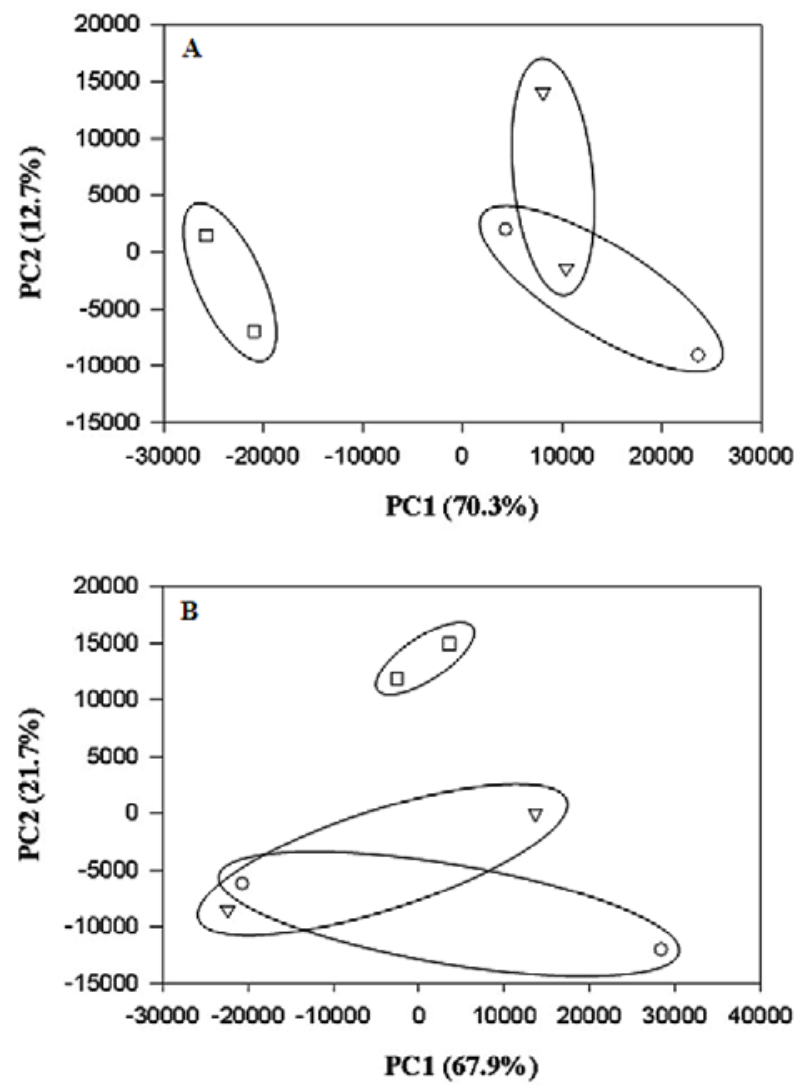

Fig. 3. Scores from a principal component analysis (PCA) on T-RF profiles of rice field soils under conventional farming $(\bigcirc)$, conventional farming with barley rotation $(\triangle)$, and organic farming ( $\square$ ) for the HaeIII dataset (A) and the HhaI dataset (B). The ellipses were drawn arbitrarily for grouping.

were significantly different from those under conventional practice (Fig. 4). However, soils under conventional practices with and without barley rotation did not differ at the $95 \%$ significance level.

\section{Characteristic Species Candidates for Each Community}

To identify characteristic species for soils under organic farming practice, we investigated the loadings for the first principal component (PC1) of the PCA for the HaeIII dataset and the second principal component (PC2) of the PCA for the HhaI dataset. We used significant loading values and their corresponding T-RF peaks to identify bacteria species candidates (Table 1). Since scores for T-RF profiles of soils under organic farming are located on the negative side on the first principal component in the HaeIII dataset and on the positive side on the second principal component in the HhaI dataset (Fig. 3), peaks with negative loadings for the HaeIII dataset and positive loadings for the HhaI dataset were expected as characteristic peaks for soils under organic farming. Only two T-RF length pairs (219/367 bp and 225/373 bp) showed significant (>0.1)

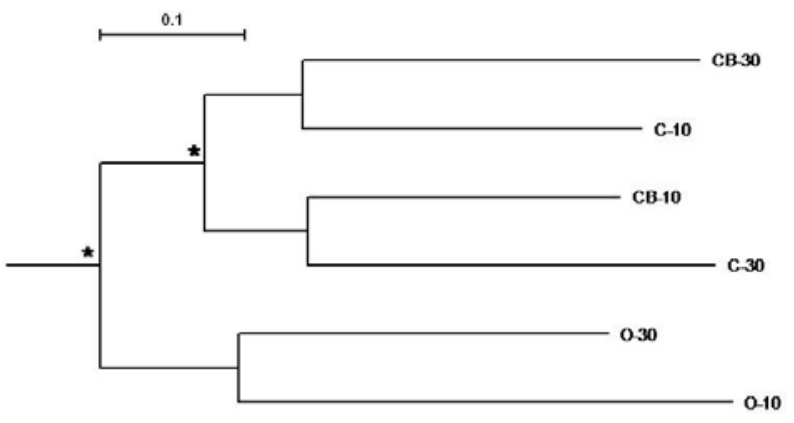

Fig. 4. A dendrogram from a cluster analysis of the projected bacterial community structures of soils under conventional farming (C-10 and C-30), conventional farming with barley rotation (CB-10 and CB-30), and organic farming (O-10 and O-30). * indicates significant linkages based on bootstrap resampling tests. The scale indicates distance on Bray-Curtis similarity.

negative loadings for PC1 from the HaeIII dataset and significant positive loading for PC2 from the HhaI dataset. The RDPII database suggested 5 species candidates (Idobacter fluviatile, Methylophylus methylotrophus, Mycobacterium intracellulare, Mycobacterium marium, and Telluria mixta) for the 219/367 pair and 4 species candidates (Kingella denitrifians, Methylobacillus flagellatum, Neisseria denitrifians, and Vitreoscilla strecoraria) for the 225/373 pair. Three T-RF length pairs (233/210, 233/63, and 233/91 bp in the HaeIII and HhaI datasets, respectively) showed significant positive loadings for both PC1 from the HaeIII dataset and PC2 from the HhaI dataset. Only one significant loading was found for 13 and 12 T-RF length.

\section{Comparisons of Bacterial Species Diversity}

Rank-abundance diagrams showed that soil bacterial communities under organic practices had a less steep slope than those under conventional practices with and without barley rotation in both the HaeIII and HhaI datasets (Fig. 5). Soils under organic practices had fewer $T$ - $R F$ peaks ( $47 \pm 1.4$, mean $\pm \mathrm{SD}$ ) than soils under conventional practices with barley rotation $(55 \pm 2.8)$ but more than soils under conventional practices without barley rotation $(46 \pm 2.1)$ in the HaeIII dataset. In the HhaI dataset, soils under organic practices displayed more $T-R F$ peaks ( $43 \pm 5.7$, mean \pm SD) than soils under conventional practices with $(37 \pm 8.5)$ and without barley rotation (42 \pm 2.8$)$.

T-RF peaks in soils under organic farming showed significantly higher diversity than those in soils under conventional farming (Table 2). The Pielou's Evenness Index and the reciprocal of the Simpson index for organic-farming soils were significantly higher than those of soils under conventional practices with and without barley rotation for both the HaeIII and HhaI datasets. 
Table 1. Bacteria species list from the RDPII site based on terminal restriction fragment (T-RF) lengths from T-RFLP using HaeIII and HhaI enzymes and loadings from principal component analyses on T-RFLP profiles. Loadings for the first principal component (PC1) are shown for the HaeIII dataset and loadings for the second principal component (PC2) are shown for the HhaI dataset

\begin{tabular}{|c|c|c|c|c|}
\hline \multirow{2}{*}{ Species } & \multicolumn{2}{|c|}{ T-RF length } & \multicolumn{2}{|c|}{ Loadings } \\
\hline & HaeIII & HhaI & HaeIII (PC1) & HhaI (PC2) \\
\hline Iodobacter fluviatile ATCC 33051 (T) & 219 & 367 & -0.164 & 0.281 \\
\hline Methylophilus methylotrophus str. AS1 ATCC 53528 (T) & 219 & 367 & -0.164 & 0.281 \\
\hline Mycobacterium intracellulare CDC1214 & 219 & 367 & -0.164 & 0.281 \\
\hline Mycobacterium marium & 219 & 367 & -0.164 & 0.281 \\
\hline Telluria mixta ACM $1762(\mathrm{~T})$ & 219 & 367 & -0.164 & 0.281 \\
\hline Kingella denitrifians str. UB-38 CCUG 30450 (T) & 225 & 373 & -0.153 & 0.249 \\
\hline Methylobacillus flagellatum str. KT1 & 225 & 373 & -0.153 & 0.249 \\
\hline Neisseria denitrifians str. M37 ATCC 14686 (T) & 225 & 373 & -0.153 & 0.249 \\
\hline Vitreoscilla stercoraria ATCC 15218 (T) & 225 & 373 & -0.153 & 0.249 \\
\hline Kurthia zopfii str. F64/100 ; K5 ATCC 33403 (T) & 233 & 210 & -0.179 & -0.162 \\
\hline Kurthia zopfii str. F64/100 ; K5 NCIMB 9878 (T) & 233 & 210 & -0.179 & -0.162 \\
\hline Salinicoccus roseus DSM 5351(T) & 233 & 63 & -0.179 & -0.297 \\
\hline Bdellovibrio stolpii str. UKi2 ATCC 27052 (T) & 233 & 91 & -0.179 & -0.476 \\
\hline Eikenella corrodens FDC 373 & 225 & 554 & -0.153 & \\
\hline Listeria grayi CIP 6818 & 233 & 578 & -0.179 & \\
\hline clone CO28 & 233 & 211 & -0.179 & \\
\hline clone OCS24 & 226 & 81 & -0.186 & \\
\hline Thermobispora bispora str. R51 ATCC 19993 (T) [gene=rrnD] & 226 & 376 & -0.186 & \\
\hline Bacillus megaterium DSM $32(\mathrm{~T})$ & 233 & 578 & -0.179 & \\
\hline Erythrobacter longus str. Och 101 ATCC 33941 (T) & 193 & 82 & 0.184 & \\
\hline Flavobacterium johnsoniae str. MVX. 1.1.1 ATCC 17061 (T) & 262 & 90 & 0.184 & \\
\hline Methylocystis M str. M & 193 & 229 & 0.184 & \\
\hline Porphyrobacter KK351 str. KK351 & 193 & 82 & 0.184 & \\
\hline Porphyrobacter neustonensis DSM 9434 & 193 & 82 & 0.184 & \\
\hline Porphyrobacter tepidarius str. OT3 DSM 10594 (T) & 193 & 82 & 0.184 & \\
\hline str. JTB20 & 193 & 95 & 0.184 & \\
\hline str. LSv54 & 193 & 95 & 0.184 & \\
\hline Paenibacillus macquariensis str. 673 DSM 2 (T) & 293 & 241 & 0.346 & \\
\hline Sphingomonas DhA-95 str. DhA-95 & 293 & 82 & 0.346 & \\
\hline str. CD & 293 & 82 & 0.346 & \\
\hline unnamed organism & 200 & 367 & & 0.281 \\
\hline clone Sva0864 & 259 & 373 & & 0.249 \\
\hline Anaerobranca horikoshii str. JW/YL-138 DSM 9786 (T) & 230 & 369 & & 0.190 \\
\hline Anaerobranca horikoshii str. JW/YL-138 DSM 9786 (T) & 230 & 369 & & 0.190 \\
\hline Desulfovibrio desulfuricans str. E1 Agheila Z NCIMB 8380 & 230 & 369 & & 0.190 \\
\hline Micrococcus luteus str. Hucker S66 ATCC 381 & 228 & 369 & & 0.190 \\
\hline clone SJA-102 & 214 & 202 & & 0.131 \\
\hline Listeria ivanovii subsp. Ivanovii str. SLCC 2379 NCTC 11846 (T) & 232 & 577 & & 0.115 \\
\hline Listeria seeligeri NCTC $11856(\mathrm{~T})$ & 232 & 577 & & 0.115 \\
\hline Thermodesulfovibrio TGL-LS1 str. TGL-LS1 & 228 & 550 & & 0.112 \\
\hline Clostridium cochlearium ATCC 17787 (T) & 224 & 363 & & 0.107 \\
\hline clone SJA-121 & 232 & 213 & & -0.127 \\
\hline str. JTB255 & 325 & 213 & & -0.127 \\
\hline str. NKB18 & 232 & 213 & & -0.127 \\
\hline Agromyces mediolanus str. CNF 186 ; K. AN-15 JCM 9632 & 229 & 370 & & -0.284 \\
\hline Arthrobacter sp. Str. RC100 & 229 & 370 & & -0.284 \\
\hline Clavibacter xyli subsp. Cynodontis str. Cxc & 230 & 370 & & -0.284 \\
\hline clone Adriatic33 & 211 & 91 & & -0.476 \\
\hline Myxococcus coralloides str. M2 ATCC 25202 (T) & 203 & 91 & & -0.476 \\
\hline
\end{tabular}




\section{DISCUSSION}

Our results showed that T-RFLP could detect differences in bacterial communities among soils of farms using different farming
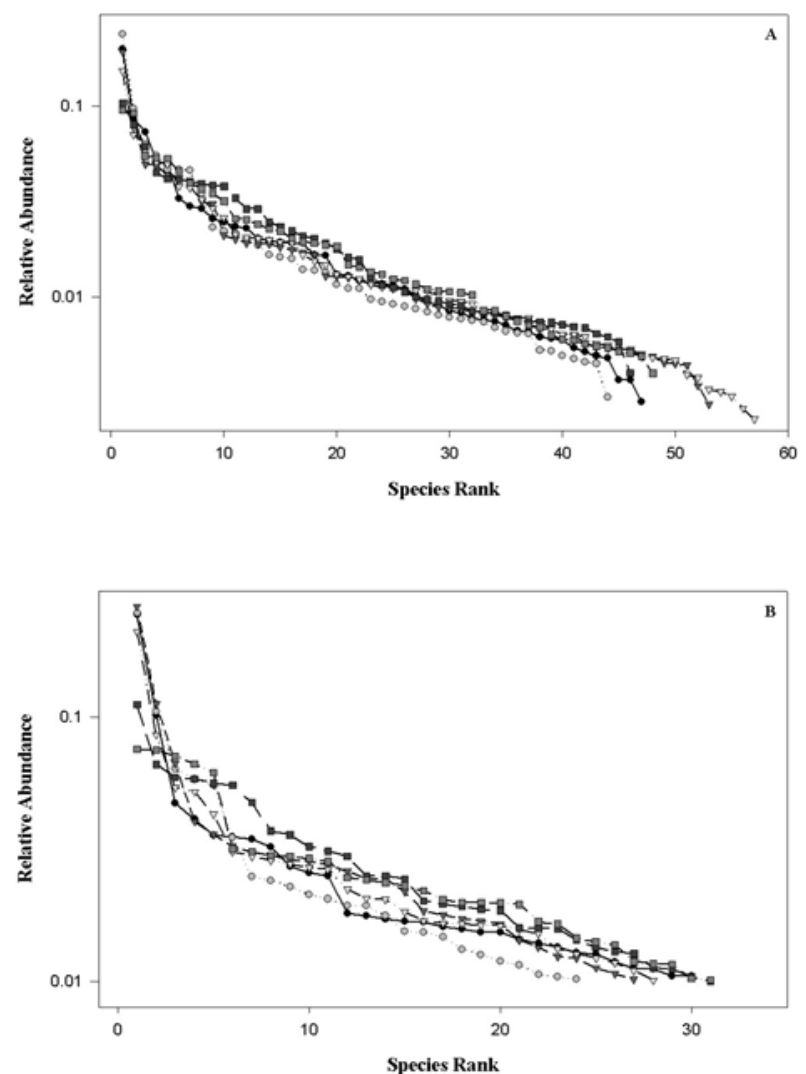

Fig. 5. Rank-abundance diagram for genotypes based on restriction fragments from the six soil bacteria communities under conventional $(\mathbf{O})$, conventional with barley rotation $(\boldsymbol{\Delta})$, and organic farming practices ( $\square$ ) for HaeIII dataset (A) and HhaI dataset (B). practices. PCA scores and cluster analysis indicated that soil bacterial communities under organic farming were clearly different from those produced by conventional farming with and without barley rotation, whereas T-RFLP could not detect the impacts of barley rotation on soil bacterial communities under conventional practices. Our findings are consistent with the results of previous studies that found significant differences between soil bacterial communities under conventional and organic farming practices using phospholipid fatty acids (PLFA) (Bossio et al. 1998, Esperschütz 2007) and using both community level substrate utilization (CLSU) and TRFLP (Widmer et al. 2006). Hartmann et al. (2006) reported that the differences in soil bacterial communities under organic practices and conventional practices were mainly due to the application of manure to organically farmed soils, which suggests a possible mechanism underlying our results.

Our PCA loading results suggest candidates for the bacterial species with high abundance in organic-farm soil (Table 1). Among the candidates for the 219/367 pair, Mycobacterium has been known to occur in acid soils or in soils with high organic contents (Iivanainen et al. 1993, Iivanainen et al. 1999) and Telluria mixta was reported to be related to peat (Green et al. 2004). Therefore, Mycobacterium and Telluria mixta appear to be reasonable candidate bacteria for rice paddy field sediments with high organic matter supplies. However, we were not able to find any relevant literature for 4 candidates for the 225/373 pair that would suggest their suitability as candidates for soils under organic farming practices. It is notable that the candidate bacterial species were only identified based on the 16S rRNA gene sequence database at RDP II site. Our approach in identifying candidate bacterial species based on T-RF length has several limitations. First, it is very hard to assign a single species candidate to a given T-RF pair. In our case, two meaningful T-RF pairs were assigned to 4 or 5 candidates. Also, it is possible that multiple species in the soil may produce the same T-RF peaks

Table 2. Comparison of species richness $(S)$, Shannon diversity index $\left(H^{\prime}\right)$, Pielou's evenness index $(E)$, and reciprocal of Simpson index $(1 / D)$ for each farming practice: conventional, conventional with barely rotation, and organic. Average values $(n=2)$ for each site are shown with standard deviations in parentheses. Superscripts ( $a$ and $b$ ) indicate results from Tukey multiple comparisontests among the samples (95\% significance level)

\begin{tabular}{clcccc}
\hline \hline Endonuclease & \multicolumn{1}{c}{ Sites } & \multicolumn{1}{c}{ S } & $H^{\prime}$ & $E$ & $1 / D$ \\
\hline \multirow{3}{*}{ HaeIII } & Conventional & $46(2.1)^{\mathrm{a}}$ & $4.618(0.1686)^{\mathrm{a}}$ & $0.838(0.0203)^{\mathrm{a}}$ & $15.27(1.030)^{\mathrm{a}}$ \\
& Conventional with barley rotation & $55(2.8)^{\mathrm{a}}$ & $4.998(0.1239)^{\mathrm{a}}$ & $0.864(0.0103)^{\mathrm{ab}}$ & $23.58(3.630)^{\mathrm{ab}}$ \\
& Organic & $47(1.4)^{\mathrm{a}}$ & $5.049(0.0187)^{\mathrm{a}}$ & $0.909(0.0037)^{\mathrm{b}}$ & $25.76(1.676)^{\mathrm{b}}$ \\
\hline \multirow{3}{*}{ HhaI } & Conventional & $42(2.8)^{\mathrm{a}}$ & $4.481(0.0382)^{\mathrm{a}}$ & $0.832(0.0221)^{\mathrm{a}}$ & $11.77(0.566)^{\mathrm{a}}$ \\
& Conventional with barley rotation & $37(8.5)^{\mathrm{a}}$ & $4.442(0.3621)^{\mathrm{a}}$ & $0.855(0.0148)^{\mathrm{a}}$ & $12.50(3.098)^{\mathrm{a}}$ \\
& Organic & $43(5.7)^{\mathrm{a}}$ & $4.994(0.1730)^{\mathrm{a}}$ & $0.921(0.0004)^{\mathrm{b}}$ & $28.04(2.083)^{\mathrm{b}}$ \\
\hline
\end{tabular}


with a given restriction enzyme. While finding important T-RF peaks using loading values may be useful in T-RFLP analysis as well as PLFA (Esperschütz et al. 2007) we obtained only two T-RF peaks that permitted further identification, partly due to statistical software that provided loadings only above a certain threshold. Overall, it appears to be very difficult to get detailed bacterial species information from T-RFLP and the 16S rRNA gene sequence database at this time. Recent reports showed variation between observed and true T-RF lengths depending on the purine content, which supports our conclusion that T-RFLP provides poor results for species identification (Kaplan and Kitts 2003, Takeshita et al. 2007).

T-RF peaks in T-RFLP can be interpreted as genotypes of the 16S rRNA gene, and several diversity indices using T-RF peaks in T-RFLP have been used to assess microbial diversity patterns (Morris et al. 2002, Denaro et al. 2005, Noguez et al. 2005, Saikaly et al. 2005). Our results indicate that relative abundances of bacterial genotypes were more evenly distributed in soils under organic practices than conventional practices (Fig. 5, Table 2). However, diversity indices such as the Shannon diversity index $\left(H^{\prime}\right)$ and genotype richness (S) did not show any differences among soil bacterial genotypes under different farming practices. The genotype richness index may have low resolving power because T-RF peaks with low fluorescence intensity would be easily ignored in T-RFLP. Also, genotype richness indices exhibited variability depending on the restriction enzymes used. Variability in genotype richness was also reported in other studies (Moeseneder et al. 2001, Saikaly et al. 2005).

Although T-RFLP has several merits over other PCR related methods (Marsh 1999), our results revealed that T-RFLP has limited ability to generate bacterial species lists for different communities through reference to the sequence database. Recent studies have shown that some limitations of T-RFLP can be overcome by combining it with cloning (Moesceneder et al. 2001, Wang et al. 2004, Kibe et al. 2004, Widmer et al. 2006).

In conclusion, our results showed that T-RFLP could detect differences in the bacterial community of soils under different farming practices. In addition, we were able to identify some important bacterial species candidates occurring under organic farming practices. However, T-RFLP and reference to the sequence database allowed us to identify only a limited list of candidate bacterial species for different communities. In addition, rank-abundance diagrams and diversity indices using T-RF peaks revealed that organic soil bacterial genotypes were more evenly distributed than soil bacterial genotypes under conventional farming practice.

To further our understanding of soil microbial community structure and function under different management practices, we will need to obtain more information about microbial species and functional groups of soil ecosystems in rice paddy fields.

\section{ACKNOWLEDGMENTS}

This research was supported by the grants from the Crop Functional Genomics Center, the Korea Science and Engineering Foundation (KOSEF) funded by the Ministry of Science and Technology, and Intramural Research Funds by Ajou University granted in 2005.

\section{LITERATURE CITED}

Bossio DA, Scow KM, Gunapala N, Graham KJ. 1998. Determinants of soil microbial communities: Effects of agricultural management, season, and soil type on phospholipid fatty acid profiles. Microbial Ecol 36: 1-12.

Chung H-S. 2003. The distributional characteristics of organic farming in South Korea. Korean J Regional Geography 9: 329-348. (in Korean)

Denaro R, D’Auria G, Di Marco G, Genovese M, Troussellier M, Yakimov MM, Giuliano L. 2005. Assessing terminal restriction fragment length polymorphism suitability for the description of bacterial community structure and dynamics in hydrocarbon-polluted marine environments. Environ Microbiol 7: 78-87.

Drinkwater LE, Letourneau DK, Workneh F, van Bruggen AHC, Shennan, C. 1995. Fundamental differences between conventional and organic tomato agroecosystems in California. Ecol Appl 5: 10981112.

Esperschütz J, Gattinger A, Mäder P, Schloter M, Flie $\beta$ bach, A. 2007. Response of soil microbial biomass and community structures to conventional and organic farming systems under identical rotations. FEMS Microbiol Ecol 61: 26-37.

Green SJ, Michel Jr FC, Hadar Y, Minz D. 2004. Similarity of bacterial communities in sawdust- and straw-amended cow manure composts. FEMS Microbiol Lett 233: 115-123.

Hartmann M, Fließbach A, Oberholzer H-R, Widmer F. 2006. Ranking the magnitude of crop and farming system effects on soil microbial biomass and genetic structure of bacterial communities. FEMS Microbiol Ecol 57: 378-388.

Iivanainen E, Martikainen PJ, Väänänen P, Katila M-L. 1999. Environmental factors affecting the occurrence of mycobacteria in brook sediments. J Appl Microbiol 86: 673-681.

Iivanainen EK, Martikainet PJ, Väänänen P, Katila M-L. 1993. Environmental factors affecting the occurrence of mycobacteria in brook waters. Appl Environ Microb 59: 398-404.

Kaplan CW, Kitts CL. 2003. Variation between observed and true terminal restriction fragment length is dependent on true TRF length and purine content. J Microbial Methods 54: 121-125.

Kibe R, Sakamoto M, Hayashi H, Yokota H, Benno Y. 2004. Maturation of murine cecal microbiota by terminal restriction fragment length polymorphism and 16S rRNA gene clone libraries. FEMS Microbiol Lett 235: 139-146. 
Liu WT, Marsh TL, Cheng H, Forney LJ. 1997. Characterization of microbial diversity by determining terminal restriction fragment length polymorphisms of genes encoding 16S rRNA. Appl Environ Microb 63: 4516-4522.

Mäder P, Flie $\beta$ bach A, Dubois D, Gunst L, Fried P, Niggli U. 2002. Soil fertility and biodiversity in organic farming. Science 296: 1694-1697.

Marsh TL. 1999. Terminal restriction fragment length polymorphism (T-RFLP): an emerging method for characterizing diversity among homologous populations of amplification products. Curr Opin Microbiol 2: 323-327.

McKenna JE Jr. 2003. An enhanced cluster analysis program with bootstrap significance testing for ecological community analysis. Environ Modell Softw 18: 205-220.

Moeseneder MM, Winter C, Arrieta JM, Herndl GJ. 2001. Terminalrestriction fragment length polymorphism (T-RFLP) screening of a marine archaeal clone library to determine the different phylotypes. J Microbiol Meth 44: 159-172.

Morris CE, Bardin M, Berge O, Frey-Klett PF, Fromin N, Girardin H, Guinebretière M-H, Lebaron P, Thiéry JM, Troussellier M. 2002. Microbial biodiversity: Approaches to experimental design and hypothesis testing in primary scientific literature from 1975 to 1999. Microbiol Mol Biol Rev 66: 592-616.

Nannipieri P, Ascher J, Ceccherini MT, Landi L, Pietramellara G, Renella G. 2003. Microbial diversity and soil functions. Eur J Soil Sci 54: 655-670.

Neher DA. 1999. Soil community composition and ecosystem processes. Agrofor Syst 45: 159-185.

Noguez AM, Aria HT, Escalante AE, Forney LJ, Garcia-Oliva F, Souza V. 2005. Microbial macroecology: highly structured prokaryotic soil assemblages in a tropical deciduous forest. Global Ecol Biogeogr 14: 241-248.

Park S, Ku YK, Seo MJ, Kim DY, Yeon JE, Jeong S-C, Yoon WK, Kim HM. 2006a. The characterization of bacterial community structure in the rhizosphere of watermelon (Citrullus vulgaris Schard.) using culture-based approaches and terminal fragment length polymorphism (T-RFLP). Appl Soil Ecol 33: 79-86.

Park S, Ku YK, Seo MJ, Kim DY, Yeon JE, Lee KM, Jeong S-C, Yoon WK, Harn CH, Kim HM. 2006b. Principal component analysis and discriminant analysis (PCA-DA) for discriminating profiles of terminal restriction fragment length polymorphism (TRFLP) in soil bacterial communities. Soil Biol Biochem 38: 23442349.

Park S. 2007. Methods for environment risk assessment of transgenic crops. In: Plant Transformation (Korean Society for Plant Genetic Transformation, ed). Jungmunkag, Seoul. Korea. pp 463-475. (in Korean)

Ritchie NJ, Schutter ME, Dick RP, Myrold RD. 2000. Use of length heterogeneity PCR and fatty acid methyl ester profiles to characterized microbial communities in soil. Appl Environ Microb 66: 1668-1675.

Saikaly PE, Stroot PG, Oerther DB. 2005. Use of 16S rRNA gene terminal restriction fragment analysis to assess the impact of solids retention time on the bacterial diversity of activated sludge. Appl Environ Microb 71: 5814-5822.

Takeshita T, Nakano Y, Yamashita Y. 2007. Improved accuracy in terminal restriction fragment length polymorphism phylogenetic analysis using a novel internal size standard definition. Oral Microbiol Immunol 22: 419-428.

Van Diepeningen AD, de Vos OJ, Korthals GW, van Bruggen AHC. 2006. Effects of organic versus conventional management on chemical and biological parameters in agricultural soils. Appl Soil Ecol 31: 120-135.

Wang M, Ahrné S, Antonsson M, Molin G. 2004. T-RFLP combined with principal component analysis and 16S rRNA gene sequencing: an effective strategy for comparison of fecal microbiota in infants of different ages. J Microbiol Meth 59: 53-69.

Widmer F, Hartmann M, Frey B, Roland K. 2006. A novel strategy to extract specific phylogenetic sequence information from community T-RFLP. J Microbiol Meth 66: 512-520.

(Received October 16, 2008; Accepted November 5, 2008) 